\title{
Oligosaccharide Elicitors and Their Receptors for Plant Defense Responses
}

\author{
オリゴ糖エリシターおよびその受容体を介した植物生体防御機構の調節
}

\author{
Yamaguchi, Takeshi ; Ito, Yuki ; and Shibuya, Naoto \\ Department of Biotechnology, National Institute of Agrobiological Resources, Ministry of Agriculture, \\ Forestry and Fisheries, 2-1-2 Kannondai, Tsukuba, Ibaraki 305-8602, Japan \\ FAX : 81-298-38-8397, E-mail : shibuya@abr.affrc.go.jp
}

Key Words : elicitor, receptor, signal transduction

\begin{abstract}
$N$-Acetylchitooligosaccharides (oligochitin, chitin oligosaccharides) of a specific size can act as potent elicitor signals for suspension-cultured rice cells as well as various plant cells which include many monocots and some dicots. We recently isolated and characterized a highly elicitor-active glucopentaose from the cell wall $\beta$-Glucan from rice blast disease fungus. The results indicated that rice and soybean cells recognize different structural units of fugal glucans as elicitor signals. Because this elicitor treatment can induce many defense reactions, it has been serving as an excellent model system for the study of the signal transduction cascade leading to the activation of defense-related genes. It is critically important to identify and characterize the receptor molecules which perceive the elicitor signal to clarify the whole signal transduction cascade. A $75 \mathrm{kDa}$ chitin oligosaccharide binding protein in the plasma membrane of suspension-cultured rice cells was identified as a putative receptor for the elicitor and purified. Recent studies on the structure and function of the binding proteins for these oligosaccharide elicitors will provide a clue to understanding how these elicitors are perceived and transduced in rice and other plant cells and also how such recognition systems have evolved.
\end{abstract}

\section{A. Introduction}

Higher plants show various stress-responses/defense reactions in response to environmental changes. These responses are often very different from those of animals and involve intra/inter-cellular signal transduction mechanisms. They have an ability to detect the invasion of pathogens and initiate defense reactions such as the biosynthesis of various antimicrobial agents and reinforcement of cell walls. These include the production of low molecular weight antimicrobial metabolites (phytoalexin) which differ from plant species, proteinase inhibitors, lignin, and cell wall glycoproteins. Compounds that can induce the defense reactions in plant have been known as "elicitors", most of which are derived from the cell surface components of pathogenic microbes or low-molecular weight compounds produced by pathogens. Natural elicitors (biotic elicitors) can be classi-
要 約

糸状菌細胞壁の構成成分であるキチンのオリゴ糖の特定サ イズのものはイネの培養細胞に対して強いエリシター活性を示 すだけではなく、単子葉植物を中心に広い範囲の植物でエリシ ターとして認識されることが示唆されている。筆者らは最近、 イモチ病菌細胞壁グルカンの䤃素分解物からイネ培養細胞に対 して強いエリシター活性を示す 1 種のグルコペンタオースを精 製し、その構造を明らかにした。その結果、イネとダイズは異 なる構造のグルカン断片をエリシターとして認識していること が示唆された。植物病原菌の感染に対する防御反応の多くが、 エリシター処理によっても再現できることから、防御関連遺伝 子発現に至るシグナル伝達過程を解析する優れたモデル系とし て、多くの研究が行われている。エリシターシグナルの受容と 伝達に関与する受容体分子を同定し、その性質を調べることは シグナル伝達機構を解明する上できわめて重要である。筆者ら はこれまでに、キチンオリゴ糖エリシターの受容体候補とし て、イネ培養細胞原形質膜上に存在する $75 \mathrm{kDa}$ のエリシター結 合タンパク質を同定しこれを精製した。このタンパク質および 及-グルカンエリシター結合タンパク質の構造と性質を調べるこ とにより、これらのオリゴ糖エリシターがイネやその他の植物 でどのように認識・伝達されていくか、また、こうした認識・ 応答系がどのように進化してきたかなどについての知見が得ら れるものと期待される。

\section{A. はじめに}

高等植物はさまざまな環境変化やストレスに対し、動物細 胞とは異なる独自のストレス応答や生体防御反応を示し、ま た、こうした応答に関わる細胞内・細胞間の情報伝達機構を備 えている。病原菌の感染に対しても、これを巧みに察知して、 さまざまな抗菌性物質を合成したり細胞壁を強固にするなどの 多様な生体防御反応を示す。前者の例としては、植物種により 異なる低分子性の抗菌性物質 (ファイトアレキシン) やプロテ アーゼインヒビターなど、後者としてはリグニンや細胞壁糖夕 ンパク質などの合成が知られている。このような一連の反応を 誘導する活性を持つ物質を総称してエリシターと呼んでいる が、その多くは病原菌細胞表層の構成成分や病原菌の産生する 低分子物質などである。生物由来のエリシターには、非病原性 遺伝子産物のようにきわめて限られた範囲の品種にのみ抵抗性 
fied into several groups which differ in the range of their specificity. For example, the elicitors derived from so-called avirulence genes are thought to induce defense reactions only in the cultivars carrying "resistance" genes. However, other elicitors such as oligosaccharide elicitors can be recognized by various plant species. In this paper, we describe the oligosaccharides derived from chitin and $\beta$-glucan which act as potent elicitors for suspension-cultured rice cells and also the receptor molecules for these oligosaccharide elicitors.

\section{B. Oligochitin elicitor}

$N$-Acetylchitooligosaccharides (oligochitin, chitin oligosaccharides) of a specific size [degree of polymerization (D.P.) $\geqq 7$ ], that can be derived from the cell walls of filamentous fungi, act as a potent elicitor for suspension-cultured rice cells (Nipponbare, BL2) at a very low concentration, even at nM (1). The elicitor activity depends on the size of $N$-acetylchito-oligosaccharides: for example, $N$-acetylchitooligosaccharides larger than hexaose (D.P.=7-8) showed very high elicitor activity at nM range but those smaller than tetraose showed only negligible activity even at a very high concentration. On the other hand, the deacetylated forms of these oligosaccharides (chitosan oligosaccharides) are inactive for suspension-cultured rice cells. Because elicitor treatment can induce many defense reactions which are induced by the invasion of pathogens in nature, it has been serving as an excellent model system for the study of the signal transduction cascade leading to the activation of defenserelated genes. We showed that the oligochitin elicitor could induce early cellular responses in the rice cells such as transient membrane depolarization $(2,3)$, ion flux (4), biosynthesis of jasmonic acid (5), reactive oxygen generation (6), and the expression of several defense-related genes $(7,8)$. Induction of chitinase acitivity or the expression of chitinase genes in rice callus and rice seeds were also reported (9-11). Oligochitin does not only induce defense reactions in rice cells but also induces lignification of wounded wheat leaves (12), activation of a specific glucanase gene in barley (13), increase of chitinase activity in melon (14), and ion flux and protein phosphorylation in cultured tomato cells (15). These observations suggest that oligochitin can be recognized as an elicitor by various plant cells which include many monocots and some dicots. Although large $\mathrm{N}$-acetylchitooligosaccharides, such as hexamer/heptamer, showed potent elicitor activity for wheat leaves, similar to rice cells, the oligosaccharides larger than biose or triose showed almost the same activity for tomato cells, suggesting that the specificity for these oligosaccharides is different among the plant species. Chitosan and its oligomers has also been reported to be an active elicitor for various dicot plants but often requires much higher concentrations for the elicitor activity $(16,17)$.
反応を誘導するものから、糖質性のエリシターのようにかなり 多くの植物が共通して認識できるものまである。ここでは、単 子葉植物であるイネに対して、強いエリシター活性を示すキチ ン系オリゴ糖ならびに $\beta$-グルカン系オリゴ糖について述べると ともに、これらに対する受容体分子の研究の現状についても紹 介する。

B. キチン系エリシター

系状菌細胞壁の構成成分であるキチンのオリゴ糖の特定サ イズ (重合度 7 以上)のものはイネ (日本晴、BL2) の培養細胞に 対して nM オーダーで非常に強いエリシター活性を示す (1)。キ チンオリゴ糖のエリシター活性はそのサイズによって大きく異 なり、7〜8 量体のようなオリゴ糖が $\mathrm{nM} レ$ レ゙ルでエリシター 活性を示すのに対して、3 量体以下の断片は高濃度でもほとん ど活性を示さない。一方、 $N$-アセチル基がアミノ基に変換され たキトサンのオリゴマーはまったく活性を示さない。植物病原 菌の感染に対する防御反応の一部が、エリシター処理によって も再現できることから、防御関連遺伝子発現に至るシグナル伝 達過程を解析する優れたモデル系として、多くの研究が行われ ている。筆者らのグループにおいても、キチン系エリシターが イネの培養細胞に対して誘導する初期反応として、膜の一過性

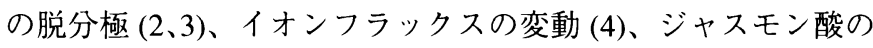
生合成 (5)、活性酸素の生成 (6)、エリシタ一応答遺伝子の発現 (7、8) などさまざまな細胞応答を見い出している。キチン系エリ シターがイネの種子やカルスにキチナーゼを誘導したり、キチ ナーゼの遺伝子発現を誘導することも明らかとなっている $(9-$ 11)。キチンオリゴ糖はイネにエリシターとして作用するだけで はなく、コムギ葉片のリグニン化誘導 (12) やオオムギグルカ ナーゼ遺伝子の発現誘導 (13)、メロンのキチナーゼ活性の増大 (14)、トマト培養細胞におけるイオンフラックスやタンパク質リ ン酸化の誘導 (15) などの活性をもつことが報告されており、単 子葉植物を中心に広い範囲の植物でエリシターとして認識され ることが示唆されている。コムギの場合はイネと同様に大きな オリゴ糖が高い活性を示すのに対してトマトでは 3 4 量体以上 はほとんど活性が変わらないなど、植物による認識特性の差異 が示唆されている。またキチンを脱アセチルして得られるキト サンとそのオリゴマーも種々の双子葉植物を中心にエリシター として作用することが知られているが、比較的高濃度のキトサ ンを要する場合が多い $(16 、 17) 。$ 


\section{Oligoglucan Elicitor}

$\beta$-Glucan fragments from the cell walls of a pathogenic fungus for soybean (Phytophthora megasperma $f$. sp. glycinea or $P$. sojae), which induce the phytoalexin biosynthesis in soybean cotyledon cells, are the best characterized glucan-related elicitor molecules for structure-activity relationships. P. Albersheim's group isolated a highly elicitor-active glucoheptaose from the partial acid hydrolysate of the $\beta$-glucan and determined its structure (18). This oligosaccharide, wellknown as the hepta- $\beta$-glucoside, has a structure with $\beta 1,6$-linked backbone and glucosyl stubs attached through 1,3-linkage and could induce phytoalexin biosynthesis in soybean cotyledon cells at $10^{-8}-10^{-9} \mathrm{M}$. Structure-activity studies with various synthetic oligosaccharides revealed that the three non-reducing end glucosyl residues are necessary for recognition, and the space between the side chains is also important for recognition. However, the elicitor activity was not affected by the modification of the non-reducing end glucosyl residue (19). On the other hand, Yoshikawa's group reported that the recognized structure in natural $\beta$-glucan elicitor is larger than the hepta- $\beta$-glucoside from the study of the elicitor activity of the $\beta$-glucan fragments prepared by $\beta-1,3$-glucanase digestion (20). We recently found that a $\beta$-glucan obtained from the cell walls of rice blast disease fungus (Pyricularia oryzae or Magnaporthe grisea) can strongly induce the phytoalexin biosynthesis in suspension-cultured rice cells. Gel filtration of the $\beta$-glucan fragments obtained by the partial hydrolysis with a purified $\beta$-1,3-glucanase on a Biogel P-4 column showed that detectable elicitor activity was distributed in the oligosaccharide fractions larger than tetraose and the activity increased in proportion to the size of the oligosaccharides. A highly elicitor-active glucopentaose which could induce phytoalexin biosynthesis at $10 \mathrm{nM}$ was purified by reversed phase HPLC. Structural analysis by methylation, acetolysis and ES/MS revealed that the glucopentaose has a structure with a
C. $\beta$-グルカン系エリシター

エリシター活性を示す $\beta$-グルカン系糖鎖として構造と機能 の関係が最もよく研究されたものに、ダイズ子葉細胞のファイ トアレキシン合成を誘導するダイズ疫病菌 (Phytophthora megasperma f. sp. glycinea またはP. sojae ) 細胞壁 $\beta$-グルカン由来 のオリゴ糖がある。Albersheim らはこの $\beta$-グルカン部分酸水解 物から、強いエリシター活性を示す 7 糖を分離し、その構造を 決定した $(18)$ 。これが良く知られているへプタ $\beta$-グルコシドで ある。 $\beta-1,6$ 結合を主鎖とし、 $\beta-1,3$ 結合を側鎖とするこの 7 糖 は数 $\mathrm{nM}$ 数十 $\mathrm{nM}$ の濃度でダイズ子葉細胞のファイトアレキシ ンの合成を誘導する活性を示した。構造的に関連した多数の才 リゴ糖が合成され、それらの活性の比較から、3つの非還元末端 グルコース残基はいずれもダイズ子葉細胞が認識するのに必須 であること、これら側鎖の間隔も厳密に認識されていること、 非還元末端の修飾は活性に影響しないことなどが明らかにされ

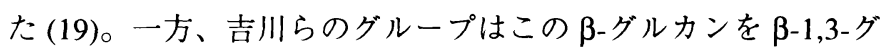
ルカナーゼで分解して得られるオリゴ糖画分の検討から実際の 認識部分八はもっと大きな単位であると考えている $(20)$ 。筆者ら は最近、イネの病原菌であるイモチ病菌 (Pyricuraria oryzae また は Magnaporthe grisea) の細胞壁由来の $\beta$-グルカンがイネ培養細 胞のファイトアレキシン合成を強く誘導することを見出した。

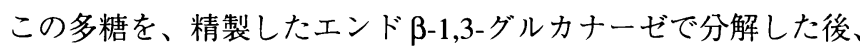
Biogel P-4のゲルろ過で、そのエリシター活性の分布を解析した 結果、この場合も重合度の高いグルカンほど、高いエリシター 活性を示した(重合度 5 以上)。さらに、逆相クロマトグラフィー で $10 \mathrm{nM}$ 以上で活性を示す最小単位八のオリゴ糖として、1 種の グルコペンタオースを精製し、メチル化、部分アセトリシス、 質量分析により構造を決定した結果、このグルコペンタオース

A

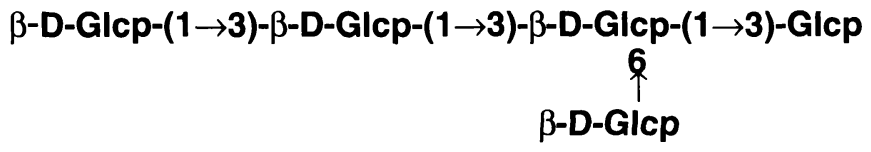

B

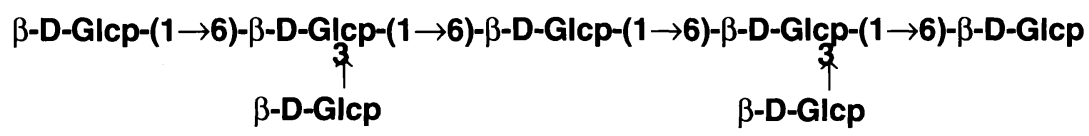

Fig. 1. Structure of the glucopentaose elicitor for cultured rice cells (A) and the glucoheptaose elicitor for soybean cotyledon cells (B). 
1,3-linked backbone and a glucosyl stub attached through 1,6linkage (21). The structure contrasts strongly with that of the elicitor-active hepta- $\beta$-glucoside for soybean cells, indicating the difference in the recognition of glucan elicitors between rice and soybean (Fig.1). In fact, an elicitor-active synthetic oligosaccharide (a hexa- $\beta$-glucoside) for soybean cells could not induce phytoalexin biosynthesis in rice cells. On the other hand, the glucopentaose purified from the cell walls of rice blast disease fungus could not act as an elicitor for soybean cells. These results suggest that the specificity of the receptors for oligoglucan elicitors has been differentiated in the course of evolution, and raise interesting questions about the structure-function relationships of the glucan receptors, possible distribution of similar systems in other plants and so on. Moreover, a synergistic effect was observed for the two types of elicitor molecules, the oligochitin and the purified oligoglucan, for the induction of phytoalexin biosynthesis in rice cells, suggesting the presence of a kind of cross-talk between the signal transduction cascades downstream of these signal molecules. Further studies on the differences of the cellular responses induced by these elicitors as well as the possible interactions between the signal transduction are under way now.

\section{Oligochitin Elicitor Binding Protein}

As described above, chitin oligosaccharides and the $\beta$ glucan oligosaccharide act as a phytoalexin elicitor on suspension-cultured rice cells at very low concentrations. This strongly indicates that the rice cells have the ability to perceive these oligosaccharides as an infection signal. However, the mechanism of the perception and transduction of the signal is largely unknown.

For example, chitin oligosacharides induce various early cellular responses such as reactive oxygen generation, ion flux and others in rice cells. These early responses may not only be the result of elicitor recognition but also play important roles in the signal transduction cascade. The specificity and the sensitivity of the eliciting activity of the chitin oligosaccharides were the same for all of the responses described above. This suggests that these responses are mediated by the same receptor molecule for chitin oligosaccharide elicitor. To understand the molecular mechanism of how plant cells perceive and transduce the elicitor signal, it is critically important to identify and characterize the receptor molecules which perceive the elicitor signal.

First of all, we employed the binding assay using an ${ }^{125} \mathrm{I}-$ labeled derivative of $\mathrm{N}$-acetylchitooctaose as a ligand to identify a high affinity binding site for the elicitor in the plasma membrane preparation from suspension-cultured rice cells $(22,23)$. The binding of the radiolabeled ligand to the plasma membrane was saturable and reversible and the Scatchard plot analysis of the results indicated the presence of a single class of binding site
は $\beta-1,3$ 結合を主鎖とし、 $\beta-1,6$ 結合を側鎖とする、枝分かれ構 造をしていることが明らかになった (21)。このオリゴ糖構造は ダイズ子葉細胞にエリシター活性を示す P. sojae 由来のオリゴ 糖とは全く対照的な構造をしており、 $\beta$-グルカン系エリシター の認識に関して、植物の間で明確な差異が存在することを示し ている(図1)。実際、ダイズに強いエリシター活性を示す合成才 リゴ糖(ヘキサ $\beta$-グルコシド)はイネのファイトアレキシン合成 を誘導せず、逆に、イモチ病菌から単離したグルコペンタオー スはダイズにはほとんどエリシター活性を示さなかった。これ らの結果は、グルカン系エリシターに対する受容体の糖鎖認識 特性が進化の過程で分かれていったことを示唆しており、こう した受容体の構造と機能、この $2 つ の$ 植物以外の植物における グルカン系エリシターの認識がどのようになっているかなど、 新たな問題を提起している。一方、精製したグルコペンタオー スは前述したキチンオリゴ糖の存在下でエリシター活性を大幅 に增強することが観察され、イネ培養細胞に対する両エリシ ターのシグナルがシグナル伝達経路のいずれかでクロストーク している可能性が示唆されている。こうした観察を基に現在、 キチン系エリシターとの間の細胞応答の差異やそれぞれのシグ ナル伝達経路間の相互作用などについて解析を進めている。

D. キチンオリゴ糖エリシター受容体

以上のように、キチンオリゴ糖およびß-グルカンオリゴ糖 はイネの培養細胞に対し、非常に低濃度で特異的にエリシター として作用する。このことは、イネ培養細胞はこれらのオリゴ 糖を感染のシグナルとして認識していることを示しているが、 そのシグナルの受容と伝達の機構はほとんどわかっていない。

キチンオリゴ糖は、活性酸素の生成やイオンフラックスを はじめとする様々な細胞初期応答反応を引き起こすが、このよ うな反応はエリシター作用の単なる結果ではなく、シグナル伝 達の過程で重要な役割を果たしている可能性が大きい。また、 これらの細胞応答におけるキチンオリゴ糖エリシターの構造に 対する特異性や感受性はほとんど同一であることから、これら がキチンオリゴ糖エリシターに対する共通の受容体を介した応 答であることが示唆された。したがって、この受容体の性質を 知ることがシグナル伝達機構の解明の上で重要な鍵となるもの と考えられる。

筆者らは、まず実際に原形質膜上にキチンオリゴ糖に結合 して受容体として機能できるような部位があるかを調べるた め、 ${ }^{125}$ 標識したキチン 8 糖をリガンドとして原形質膜への結合 試験をおこなった(22、23)。その結果、リガンドは飽和型の曲線 を示して可逆的に結合し、Scatchard 解析から一種類の結合部位 
Table I. Elicitors and their binding sites.

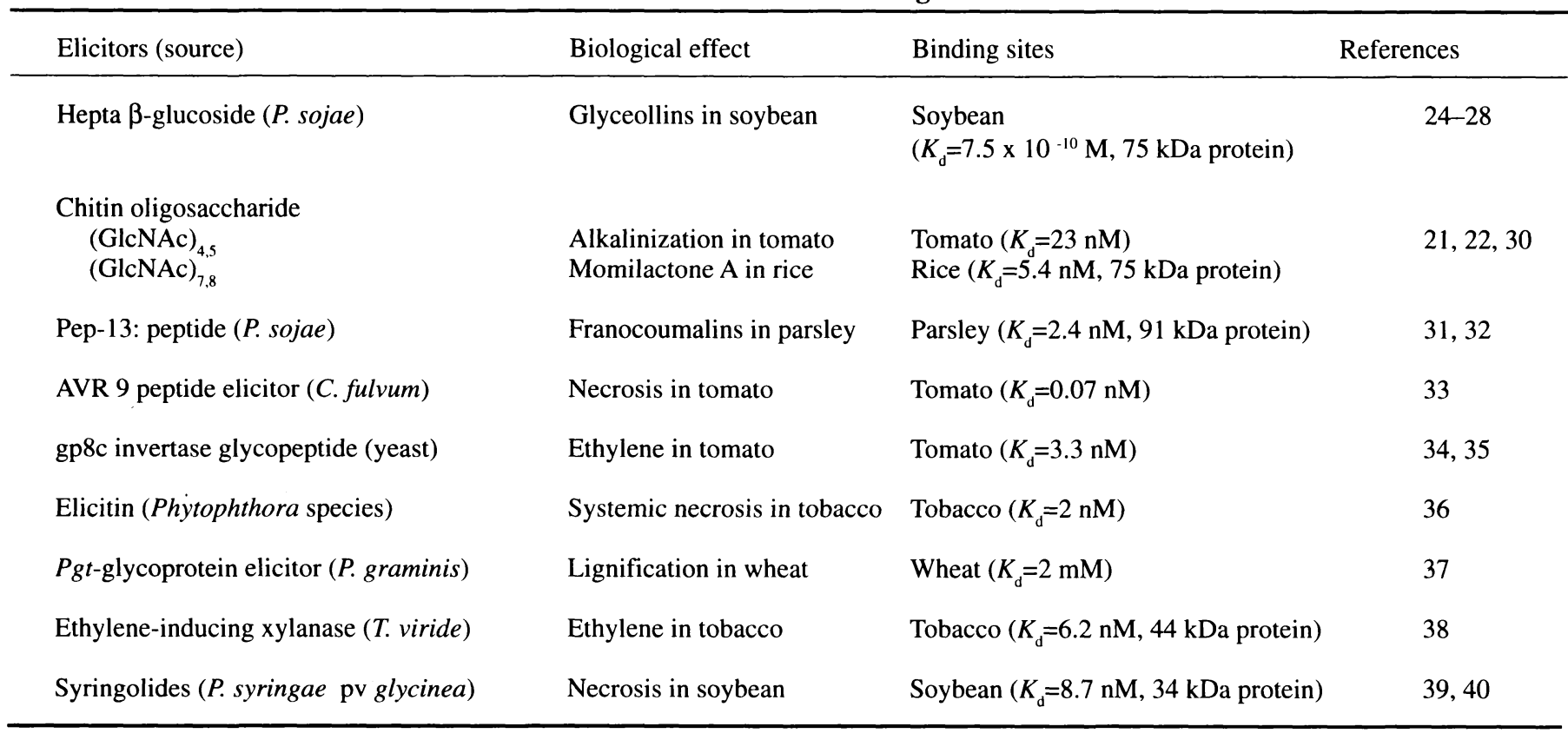

( $K_{\mathrm{d}}$ of $29 \mathrm{nM}$ ) (Table I). A series of chitin oligosaccharides of D.P. $=1$ to 8 wes tested as a competitive inhibitor for the binding. Chitin octamer inhibited $50 \%$ of the binding of the ligand at a concentration as low as $\mathrm{nM}$. The inhibiting activity of the oligosaccharides increased as the size of the oligosaccharide increased. On the other hand, chitosan octamer and cellooligosaccharides were inactive. The specificity and the sensitivity of the binding site to the chitin oligosaccharide elicitor corresponds well with the eliciting activity of the elicitor. These results demonstrated that a binding site for the chitin oligosaccharide elicitor is present in the plasma membrane of the suspension-cultured rice cells.

In order to identify the molecule corresponding to this binding site, photoaffinity labeling and affinity cross-linking with ${ }^{125}$ I-labeled derivatives of $\mathrm{N}$-acetylchitoheptaose was performed (24). A $75 \mathrm{kDa}$ plasma membrane protein was specifically labeled by the reagents and identified by the SDS-PAGE of the solubilized plasma membrane protein. The estimated molecular size of this protein did not change under reducing condition or non-reducing condition, indicating the absence of a subunit structure connected through disulfide linkage. The incorporation of the ligand into the protein was saturable and the specificity and the sensitivity of the labeling corresponds well with the binding activity of the elicitor to the binding site demonstrated by the binding assay. These results indicate that the $75 \mathrm{kDa}$ protein represents at least the binding site identified by the binding assay. The binding characteritics of the ligand to the $75 \mathrm{kDa}$ protein corresponds well with the eliciting activity of the elicitor which strongly suggests the $75 \mathrm{kDa}$ protein is the functional
$\left(K_{\mathrm{d}}=29 \mathrm{nM}\right)$ の存在が示された (表 I )。この結合はキチン 8 糖で は数 $\mathrm{nM}$ という低濃度で $50 \%$ 阻止され、キチンオリゴ糖の重合 度が大きいほど阻止活性も大きいが、キトサン8糖およびセロオ リゴ糖ではまったく阻止がみられなかった。このように、この 結合部位のリガンドに対する親和力と特異性はキチンオリゴ糖 のフィトアレキシンエリシター活性の性質と良い一致を示し、 エリシターの結合部位が原形質膜上に存在することが示され た。

この結合部位がどのような分子か知るために ${ }^{125}$ 標識したキ チン8糖の親和性標識リガンドを合成し、化学的架橋反応または 光化学反応による親和性標識を行ったところ、分子量 $75 \mathrm{kDa}$ の 原形質膜タンパク質が特異的に標識されることが見出された (24)。SDS-電気泳動によって求めたこのタンパク質の分子量は 還元剂の存在下、非存在下で変わらなかったため、SS 結合によ るサブユニット構造を持たないものと思われた。リガンドの 75 $\mathrm{kDa}$ タンパク質へのとりこみは飽和型の曲線を示し、とりこみ 阻止試験の結果から、結合タンパク質のリガンドに対する親和 力と特異性は結合試験で検出された結合部位の性質と非常に良 い一致を示した。従って、親和性標識により検出されたこの夕 ンパク質は、少なくとも結合試験で検出された結合部位そのも のであると思われる。また上で述べたキチンオリゴ糖の初期応 答などの誘導活性ともよく一致しているので、筆者らはこの夕 ンパク質はエリシターの受容体あるいはその一部である可能性 
receptor for the elicitor, or a part of it.

The purification of the $75 \mathrm{kDa}$ protein and the cloning of the gene encoding the protein is in progress in our laboratory. It is estimated from the result of the binding assay that the amount of binding protein present in the $1 \mathrm{mg}$ plasma membrane protein is as low as $1 \mu \mathrm{g}$. In addition, the amount of material available is often limited. So it is necessary to improve the sensitivity of the detection method and the yield of the purification of the protein in order to get sufficient binding protein for the sequencing. We have recently purified the $75 \mathrm{kDa}$ protein to homogeneity by both ligand affinity chromatography and avidin-biotin affinity chromatography from the plasma membrane of the suspensioncultured rice cells (unpublished). Further studies are necessary to prove the protein is really the functional receptor.

Recently, the $75 \mathrm{kDa}$ chitin oligosaccharide binding protein was also detected in the plasma membranes from rice leaves and roots. The presence of the chitin binding proteins of similar size and binding characteristics are also demonstrated in suspension-cultured cells from other plants including wheat, barley, soybean and carrot by affinity labeling (unpublished). The distribution of these binding proteins corresponded well with the responsiveness of these cells, as detected by the induction of reactive oxygen generation, to the $\mathrm{N}$-acetyl chitooligosaccharide elicitor. These results also support the functional role of these binding proteins as the receptor for this class of elicitor.

\section{E. Oligoglucan Elicitor Binding Protein}

The strict structural requirement of minimal elicitor-active glucopentaose indicates the presence of the receptor for the elicitor in the suspension-cultured rice cells. The identification and characterization of the receptor is one of our major research goals. Chemically synthesized analogues of the $\beta$-glucan elicitor will enable us to identify and purify the binding protein.

As described above, there is a clear difference in the recognition of the $\beta$-glucan elicitors in rice and soybean. The hepta $\beta$-glucoside binding protein of soybean is the best characterized elicitor binding protein $(25,26)$ (Table I). In this case, a $75 \mathrm{kDa}$ elicitor binding protein was identified in the microsomal membrane of the soybean root by affinity labeling (27). The binding protein was purified to homogeneity by ligand affinity chromatography (28) and the cDNA was cloned and sequenced (29). High-affinity binding sites of similar characteristics were also found in the microsomal fractions of Fabaceous plants other than soybean (30). Studies on the structure and function of the $\beta$-glucan elicitor binding proteins in rice and soybean, and also in other plants if present, will provide a clue to understanding how the $\beta$-glucan elicitor recognition systems with different specificity have developed in different plant species in the course of evolution.

In addition, we have found that the $\beta$-glucan elicitor acts synergistically with the chitin oligosaccharide elicitor to induce
が大きいと考えている。

現在、筆者らの研究室では $75 \mathrm{k} \mathrm{Da}$ タンパク質の精製と遺伝 子クローニングを進めている。結合試験の Scatchard 解析から、 このタンパク質は原形質膜タンパク質 $1 \mathrm{mg}$ あたり $1 \mu \mathrm{g}$ 程度と いう低濃度でしか存在しないことが予想される。しかも材料の 量が限定されるので、精製効率と検出感度を上げる工夫が必要 とされてくる。筆者らは、原形質膜タンパク質の可溶化物をキ チンオリゴ糖を固定したアフィニティーカラムで精製する方法 と、結合部位を親和性標識でビオチンラベルしアビジンカラム で精製する方法でこのタンパク質を単一バンドに精製した(未発 表)。これらの方法により精製されたタンパク質が受容体である という証明には細心の注意が必要であり、さらに検討を進めて いる。

最近、この $75 \mathrm{kDa}$ タンパク質は、イネの培養細胞だけでな く、葉、根などの組織にも存在することが親和性標識などによ り明らかに示された。また、類似の結合活性と分子量を持つ夕 ンパク質が、コムギ、オオムギ、ダイズ、ニンジンなど、イネ 以外のいくつかの植物の培養細胞原形質膜上にも存在すること が示された (未発表)。調べた範囲の種においては、活性酸素生 成応答を示す細胞には例外なくこうした結合タンパク質が存在 していた。以上の結果は、これらの結合タンパク質が実際に機 能している受容体であることを強く示唆するものである。

\section{E. $\beta$-グルカンオリゴ糖エリシター受容体}

及-グルカンオリゴ糖エリシターも、その活性最小単位が厳 密な特定の構造を持つことが決定されたことから、受容体の存 在が強く示唆される。 $\beta$-グルカンオリゴ糖結合タンパク質の存 在を同定しその性質および機能を調べることはこれからの大き な課題である。筆者らは $\beta$-グルカンオリゴ糖の合成アナログを 用いることなどにより受容体の存在を同定し精製することが可 能になると考えている。

先に述べたように、イネとダイズでは $\beta$-グルカン系エリシ タ一の認識に関して明確な差異が存在すると考えられる。ダイ ズに存在するへプタ $\beta$-グルコシド結合タンパク質は、現在最も よく性質が研究されているエリシター結合タンパク質であるが (25、26)、親和性標識によりこのタンパク質も $75 \mathrm{kDa}$ であるこ とが示されている (27) (表I)。このタンパク質は単一に精製さ れ (28)、cDNA がクローニングされ、タンパク質の構造が明ら かになった (29)。また類似の性質を示す結合タンパク質がダイ ズ以外のいくつかのマメ科植物にも存在することが示されてい る(30)。このダイズ系のへプタ $\beta$-グルコシド結合タンパク質と イネの $\beta$-グルカンオリゴ糖結合タンパク質との関係や、他の植 物種における $\beta$-グルカンオリゴ糖結合タンパク質の存在などが 明らかになると、異なる植物種でグルカン系エリシターという 同一グループに属する糖質エリシターに対する認識特性が進化 の過程でどのように分かれてきたかが明らかになると考えられ る。

また、 $\beta$-グルカンオリゴ糖はキチンオリゴ糖と相乗効果を 示すことが認められたが、予備的な結合阻止試験の結果から、 
phytoalexin biosynthesis in the rice cells. Some preliminary studies, such as the inhibition assay with the labeled chitin fragment elicitor and unlabeled glucan elicitor, indicated that the binding protein for the chitin and glucan elicitor may be the different molecules (unpublished). The rice cells seem to have independent receptors for these oligosaccharide elicitor signals that transduce the signals to the downstream cascades which are cross-talking to each other. The characterization of the binding sites on the rice cells for the two oligosaccharide elicitors will answer some of the questions of how a single plant cell recognizes and responds to two kinds of oligosaccharide elicitors.

These fundamental questions on plant-pathogen interactions will eventually be answered after the full characterization of the receptors for both elicitors.

Our work cited here wes supported in part by the Program for Promotion of Basic Research Activities for Innovative Biosciences (PRO-BRAIN), Tokyo, Japan and also by the Grantin-Aid (Glycotechnology Program) from the Ministry of Agriculture, Forestry and Fisheries, Japan. We thank all the collaborators who were involved in these projects. ß-グルカンオリゴ糖はキチンオリゴ糖結合部位とは相互作用し ない可能性が大きいことがわかってきた (未発表)。イネは二つ の糖質エリシターに対して、それぞれ独立した受容体を持ち、 それらの下流のシグナル伝達経路は何らかの形でクロストーク していることが想定される。イネ培盖細胞の二つのエリシター 結合タンパク質の解析により、二つの異なる糖質エリシターを 一つの植物がどのように認識してシグナルを伝達するのか、ま た、それらの伝達経路がどのように交差し相互作用するのかと いう興味深い問題が明らかになると考えられる。

イネのオリゴ糖エリシター受容体の研究により、このよう な病原菌・植物相互作用の基本的な問題が解明されてゆくこと を筆者らは期待している。

本稿で引用した著者らの研究は、主として生物系特定産業 技術研究推進機構 (生研機構) の基礎研究推進事業および農林水 産省プロジェクト「糖質工学」により行われたものである。こ れらの研究に参加された多くの共同研究者に厚く感謝する。

\section{References}

1. Yamada, A., Shibuya, N., Kodama, O., and Akatsuka, T. (1993) Biosci. Biotechnol. Biochem. 57, 405-409

2. Kuchitsu, K., Kikuyama, M., and Shibuya, N. (1993) Protoplasma 174, 79-81

3. Kikuyama, M. Kuchitsu, K., and Shibuya, N. (1997) Plant Cell Physiol. 38, 902-909

4. Kuchitsu, K., Yazaki, Y., Sakano, K., and Shibuya, N. (1997) Plant Cell Physiol. 38, 1012-1028

5. Nojiri, H, Sugimori, M., Yamane, H., Nishimura, Y., Yamada, A., Shibuya, N., Kodama, O, Murofushi, N., and Ohmori, T. (1996) Plant Physiol. 110, 387-392

6. Kuchitsu, K., Kosaka, T. Shiga, T., and Shibuya, N. (1995) Protoplasma 188, 138-142

7. Minami, E., Kuchitsu, K., He, D.Y., Kouchi, H., Midoh, N., Ohtsuki, Y., and Shibuya, N. (1996) Plant Cell Physiol. 37, 563-567

8. He, D.Y., Yazaki, Y., Nishizawa, Y., Takai, R., Yamada, K., Sakano, K., Shibuya, N., and Minami, E. (1998) Mol. Plant-Microbe Interact. 12, 1167-1174

9. Hirano, S., Yamamoto, T., Hayashi, M., Nishida, T., and Inui, H. (1990) Agric. Biol. Chem. 54, 2719-2720

10. Inui, H., Kosaki, H., Uno, Y., Tabata, K., and Hirano, S. (1991) Agric. Biol. Chem. 55, 3107-3109

11. Nishizawa, Y., and Hibi, T. (1991) Plant Sci. 76, 211-218

12. Barber, M.S., Bertram, R.E., and Ride, J.P. (1989) Physiol. Mol. Plant Pathol. 32, 3-12

13. Kaku, H., Shibuya, N., Xu, P, Aryan, A.P., and Fincher, G.B. (1997) Physiol. Plant. 100, 111-118

14. Roby, D., Gadelle, A., and Toppan, A. (1997) Biochim. Biophys. Res. Commun. 143, 885-892

15. Felix, G., Regenass, M., and Boller, T. (1993) Plant J. 4, 307-316

16. Hadwiger, L.A., and Beckman, J.M. (1980) Plant Physiol. 66, 205-211

17. Kauss, H., Jeblick, W., and Domard, A. (1989) Planta 178, 385-392

18. Sharp, J.K., Valent, B., and Albersheim, P. (1984 ) J. Biol. Chem. 259, 11312-11320

19. Cheng J.J., Birberg, W., Fugedi, P., Pilotti, A., Garegg, P.J., Hong,N., Ogawa, T., and Hahn, M.G. (1991) Plant Cell 3, $127-136$

20. Yoshikawa, M., Yamaoka, N., and Takeuchi, Y. (1993) Plant Cell Physiol. 34, 1163-1173

21. Yamaguchi, T. Yamada, A., Hong, N., Ogawa, T., Ishii, T., and Shibuya, N. (2000) Plant Cell (in press)

22. Shibuya, N., Kaku, H., Kuchitsu, K., and Maliarik, M.J. (1993) FEBS Lett. 329, 75-78

23. Shibuya, N., Ebisu, N., Kamada, Y., Kaku, H., Cohn, J., and Ito, Y. (1996) Plant Cell Physiol. 37, 894-898

24. Ito, Y., Kaku, H., and Shibuya, N. (1997) Plant J. 12, 347-356

25. Cheong, J.J., and Hahn, M.G. (1991) Plant Cell. 3, 137-147

26. Cosio, E.G., Popperl, H., Schmidt, W.E., and Ebel, J. (1988) Eur. J. Biochem. 175, 309-315

27. Cosio, E.G., Frey, T., and Ebel, J. (1992) Eur. J. Biochem. 204, 235-238

28. Mithöfer, A., Lottspeich, F., and Ebel, J. (1996) FEBS Lett. 381, 203-207

29. Umemoto, N., Kakitani, M., Iwamatsu, A., Yoshikawa, M., Yamaoka, N., and Ishida, I. (1997) Proc. Natl. Acad. Sci. USA 94, 1029-1034

30. Cosio, E.G., Feger, M., Miller, C.J., Antelo, L., and Ebel, J. (1996) Planta 200, 92-99

31. Baureithel, K., Felix, G., and Boller, T. (1994) J. Biol. Chem. 269, 17931-17938

32. Nurnberger, T., Nennstiel, D., Jabs, T., Sacks, W.R., Hahlbrock, K., and Scheel, D. (1994) Cell 78, 449-460 
33. Nennstiel, D., Sceel, D., and Nurnberger, T. (1998) FEBS Lett. 431, 405-410

34. Kooman-Gersmann, M., Honee, G., Bonnema, G., and DeWit, P.J.G.M. (1997) Plant Cell 8, 929-938

35. Basse, C.W., Fath, A., and Boller, T. (1993) J. Biol. Chem. 268, 14724-14731

36. Fath, A., and Boller, T. (1996) Plant Physiol. 112, 1659-1668

37. Wendehenne, D., Binet, M.-N., Blein, J.-P., Ricci, P., and Pugin, A. (1995) FEBS Lett. 374, 203-207

38. Kogel, G., Beissmann, B., Reisener, H. J., and Kogel, K. (1991) Planta 183, 164-169

39. Hanania, U., and Avni, A. (1997) Plant J. 12, 113-120

40. Ji, C., Okinaka, Y., Takeuchi, Y., Tsurushima, T., Buzzell, R.I., Sims, J.J., Midland, S.L., Slaymaker, D., Yoshikawa, M., Yamaoka, N., and Keen, N. T. (1997) Plant Cell 9, 1425-1433

Received on March 3, 2000, accepted on March 9, 2000

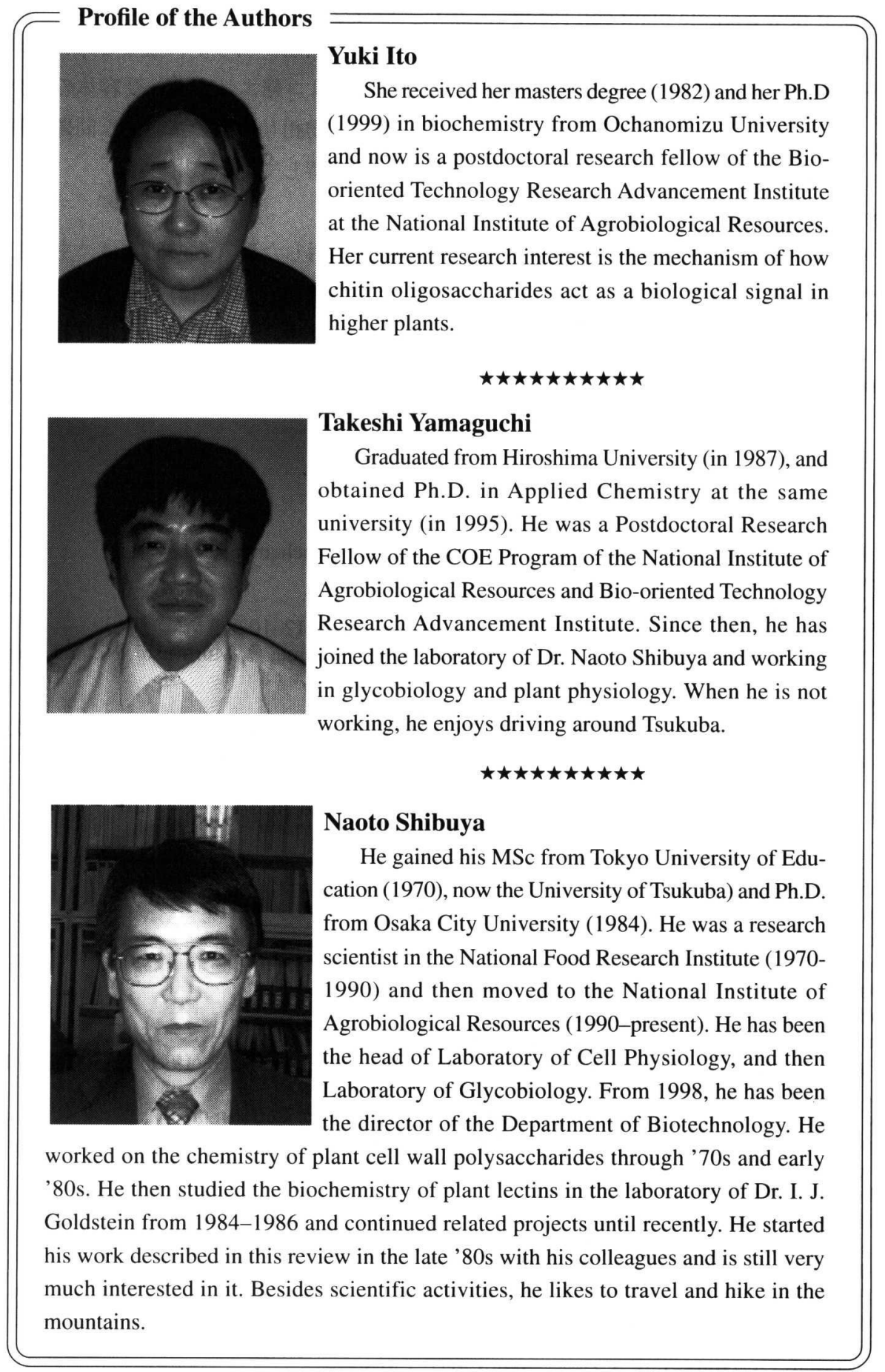

